\title{
The Role of Age, Gender and Socio-Economic Status in Self- esteem and Life satisfaction of Nursing Students
}

\author{
*Ume Farwa, Muhammad Hussain, Muhammad Afzal, Syed Amir Gilani \\ Lahore School of Nursing, The University of Lahore, Lahore, Pakistan \\ Faculty of Allied Health Sciences, The University of Lahore, Lahore, Pakistan \\ Tel: $03039122671 * E-m a i l:$ alihaidar.333haidarali@gmail.com
}

\begin{abstract}
Introduction:Self-esteem and Life satisfaction assume a more prominent role in human development. There are a few components like Age, Gender and Socio-Economic status which influence self-esteem and life satisfaction. Socio-economic status of a nation may be a factor in people's rating of their life satisfaction. Selfesteem has positive relation with students' academic learning

Methods: A descriptive correlational study was conducted at Lahore School of Nursing, The University of Lahore. Data was gathered by nursing students of BSN and Post RN. Questionnaire which was used in this study was Self-esteem inventory and Life Satisfaction scale. Reliability of the scale test by Chronbach alpha . Data was analysed by SPSS and using Pearson correlation test to see the relationship between self-esteem and life satisfaction and socioeconomic status of the nursing students.

Results: Results shows a positive correlation between self-esteem and life satisfaction. Pearson correlation level was 1.000 and p value was .000 on 0.05 confidence level of interval which shows negative correlation results. Results also revealed a positive correlation of socio-economic status with self-esteem and life satisfaction.

Conclusions: it is concluded that the relationship of socioeconomic status life satisfaction and self-esteem of the students affects their learning. High level of socioeconomic status can boost the self-esteem and life satisfaction of the students
\end{abstract}

Keywords: Self-esteem, Life satisfaction, socioeconomic status, Nursing students

DOI: $10.7176 / \mathrm{JHMN} / 62-19$

Publication date:May $31^{\text {st }} 2019$

\section{Introduction}

The students at different levels in College or University have different level of self-esteem and life satisfaction. Different levels of socio-economic status have different impact on the self-esteem of students. Personal characteristics, for example, happiness, prosperity, and self-esteem contribute to positive psychology and from various perspectives decrease the effects of discouragement. It has been resolved that an individual can emphatically or contrarily influence his level of satisfaction based on the activities that he takes part in (Boyd, Lawrence, Brooks, Perkins, \& Clark, 2018).

Age is the period of time in which a person has lived or things have existed. On average, self-esteem increases in on time and focus youth, remains unfaltering (yet does not diminish) in adolescence, increments emphatically in young adulthood, continues growing in focus adulthood, peaks between age 60 and 70 years, and after that diminishes in development, with a more sharpened drop in status (Orth, Erol, \& Luciano, 2018).

Past investigation was directed to see the relationship of age, life satisfaction, and self-esteem which demonstrates a significant relationship between age, life satisfaction, confidence, and psychological wellness. This may reflect the significance of age in anticipating life satisfaction, confidence and psychological wellness of a person. With respect to gender orientation, huge affiliation was seen among gender and life satisfaction (Okwaraji, Godwin, Callista, \& Emeka, 2017).

Gender is the distinction of male and female. Gender define a person is masculine of feminine. According to gender perspective boys has high level of self-esteem than girls. Self-esteem has positive relation with youngster's life satisfaction. Therefore, this relation is strong for both boys as well as girls (Moksnes \& Espnes, 2013).

A healthy self-esteem is necessary for mental wellbeing and it can be achieved by set of achievable positive goals and completion of the goals resulting in an increased confidence and boldness. Self-esteem, beingaw 2

viewed as a major human concern, may serve as an interceding factor among socio-economic status and life satisfaction. Susan Harter has depicted self-esteem as "the dimension of worldwide respect that one has for the self as an individual". Various extents of self-esteem reflect the conceptualization of confidence as an individual by and overall judgment or have a solitary overall certainty measurement (Thompson, 2017).

However, socio-economic status is an imperative deciding element of individuals' life satisfaction, in that the rich are happier with their life than poor people. The term Socio-Economic Status is the mix of societal position 
and financial status of a person or on the other hand family based on income, education, profession, and material had and so on in connection to others in a general public. Extensively, Socio-economic Status contained sociosocial perspectives, financial, instruction and ownership of merchandise and ventures which are benefits in a family (Islam \& Khan, 2017).

As well as, Family socio-economic status is a basic determinant of people's life satisfaction; in that the rich are typically more satisfied with their life than poor individuals. Financial status has direct impacts as well as mediated effects on prosperity. Certainty may fill in as an intervening variable among socio-economic and life satisfaction. According to the social marker or salience model, low socio-economic families experience also compromising and natural life events and stress and financially loaded young people are at higher threat of helplessness, feebleness, and low confidence (Chen et al., 2016).

Socio-economic status did not remain constant. It changes according to family situation. The component of income in socio-economic status changes every year. So that, the recent socio-economic scale should be used by the researcher in community health studies (Singh, Sharma, \& Nagesh, 2017).

Confidence in one's own and satisfaction with life speak to general assessments: self-esteem reflects an individual's assessments of oneself, while life satisfaction includes a person's assessment of his or her life as a whole. However, self-esteem is the most observable factor in students. It is typically tended to in the midst of in school period. It is a sincere conviction of oneself and is shaped by individuals' relationships with others, encounters, and accomplishments for the duration of regular day to day existence. A sound confidence is important for mental prosperity and a positive self-thought. This is practiced by characterizing reachable targets and adequately accomplishing the goals, achieving a development in confidence, insistence, and feeling esteemed. Since self-esteem impacts on all parts of life, it is essential to develop a sound, reasonable point of view on oneself (Tiwari, Singh, Lindinger-Stern Art, \& Patel, 2018).

However Socio-social contrasts impact life spaces, for instance, prosperity, lifestyle, and achievement, feeling safe, the get-together of people you have a spot with, security for the future or relational associations. Happiness is determinedly associated with employment and nature of work, pay, social associations and mental and considerable prosperity results. In particular, people with anomalous states on fulfillment are progressively relaxed, can deal with their sentiments better and are progressively fit for standing up to and enduring issue (Bieda et al., 2019) .

The relationship between financial status (SES) and behavior problems in youngsters is for quite some time built up and all around acknowledged. Crosswise over dimensions of socio-economic status, behavior problems are commonly increasing regularly among lower socio-economic status children. In any case, less is understood about both the mechanisms that underlie these distinctions and their formative causes (McGrath \& Elgar, 2015). Perceptions were based on instructor's childhood, conviction framework, sex, race, and class. Students at high financial schools were seen to be pioneers, fashionable, supported by families. Interestingly, students at low financial schools were seen to require order and structure, chances to accumulate basic information, and support from guardians (Norman, 2016).

Whereas, there is a widespread thought that people's characteristics can clarify why some are happier with life than others in a similar domain. Among components that incorporate family, companions, account, and culture, coarseness is an essential indicator of life satisfaction (Li, Fang, Wang, Sun, \& Cheng, 2018) .

Satisfaction with life is moderately a steadier trademark than full of feeling segments and it has broad advantages to the mental wellbeing and personal satisfaction of people. Satisfaction with life enables people to perform long term life assessments dependent on their own sets of criteria (Robustelli \& Whisman, 2018).

Life satisfaction is a vital form in constructive brain research and evaluate an individual's general examination of individual fulfilment reliant on his or her picked criteria, including the perception that one is progressing towards fundamental life targets though Self-esteem reflects a person's observation of himself or herself. Previous study demonstrated connection between self-esteem and number of things created in classes, for example, connected exercises, positive characteristics and names of friends (Tiwari et al., 2018).

Furthermore, a moderate dimension or abnormal state of confidence is by all accounts a pre-essential for sound human working. Most people with a high or moderate dimension of self-esteem see themselves more positively (Tiwari et al., 2018).

Personal satisfaction, self-esteem and attribution styles effects on people's individual and social capacities. An examination demonstrates a critical positive relationship among measurements of personal satisfaction and confidence. Besides, there was a significant negative connection between self-esteem and negative state of mind and all parts of personal satisfaction were huge indicators of self-esteem (Kazemi, Nikmanesh, \& Khosravi, 2017).

\section{2: AIMS OF THE STUDY}

- To find out the relationship between self-esteem and life satisfaction among nursing students 
To assess the influence of socio-economic status on self-esteem and life satisfaction nursing students

\section{3: SIGNIFICANCE OF THE STUDY}

The result of this study will help to overcome the problems of age, gender and socio-economic status which influence the self-esteem and life satisfaction among nursing students. Policymakers of organization can minimize the problems of nursing students related to age, gender and socio-economic status which cause low self-esteem, through conducting seminars and workshops, which enhances the self-esteem and life satisfaction of students. They can create a distinct environment for each student to boost their self-esteem and life satisfaction because enhancing of self-esteem can improve the learning abilities of the students, As study shows that there is a positive correlation between self-esteem and academic achievement (HANAFI, EL-BILSHA, \& KHATER, 2016 ). Another study shows that self-esteem has positive relation with students' academic learning (Körük, 2017). Furthermore, the quality of learning will be improved in the organization which will enhance organizational prestige.

\section{LITERATURE SEARCH}

Life satisfaction is a vital form in constructive brain research and evaluate an individual's general examination of individual fulfillment reliant on his or her picked criteria, including the perception that one is progressing towards fundamental life targets though self-esteem reflects a person's observation and assessment of himself or herself. Previous study demonstrated reliable connection between self-esteem and number of things created in classes, for example, connected exercises, positive characteristics and names of friends (Tiwari et al., 2018).

An examination showed that Females had lower certainty levels than young men anyway bigger measures of fulfillment with their life and progressively raised measures of subjective happiness. Guys had increasingly raised measures of certainty yet lower measurements of fulfillment with life and lower happiness levels. As such, there is an association between confidence and both fulfillment with life and subjective happiness (Hill, 2015).

Past investigation was led to see the relationship of age, life fulfillment, and confidence which demonstrates a significant relationship between age, life satisfaction, confidence, and psychological wellness. This may reflect the significance of age in anticipating life satisfaction, confidence and psychological wellness of a person. With respect to gender orientation, huge affiliation was seen among gender and life satisfaction (Okwaraji, Godwin, Callista, and Emeka, 2017).

Personal satisfaction, self-esteem and attribution styles effects on people's individual and social capacities. An examination demonstrates a critical positive relationship among measurements of personal satisfaction and confidence. Besides, there was a significant negative connection between self-esteem and negative state of mind (from segments of quality of life) and all parts of personal satisfaction were huge indicators of self-esteem (Kazemi, Nikmanesh, and Khosravi, 2017).

Relationship between self-esteem and number of things produced in classifications, for example, connected exercises, positive characteristics and names of companions. People with low confidence put little an incentive on themselves and their achievements. Individuals feel that they are bad enough and that they are worth short of what others and regularly feel embarrassed about them. They participate in negative self-talk, much of the time apologize, and look for consistent consolation (Tiwari et al., 2018).

Spiritual health is one of the elements of well-being without which different elements of well-being can't be ideally proficient. An investigation demonstrates huge connection between spiritual well-being and happiness just as their consequences for different components of well-being and in improving students' performance, making arrangements for expanding delight and spiritual well-being are essential (Arani, Hoseini, \& Hamzeei, 2018).

Previous studies shows that there was a negative connection of Socio-economic status with self-esteem, positive thinking, and life satisfaction. Furthermore, self-esteem was positively corresponded with good faith and life satisfaction. Finally, idealism was positively associated with life satisfaction. Optimism can shield financially disadvantaged young people's confidence from being threatened (Chen et al., 2016).

A few studies demonstrate the impact of four financial components education, well-being, salary level and family measure on the existence satisfaction of individuals. The aftereffects of the examination demonstrated that there was a huge relationship of education, well-being and family unit measure with life satisfaction. However, income did not predict life satisfaction. Education was the most grounded indicator of life satisfaction when contrasted with other economic factors (Mafini, 2017).

Study indicated connections between societal position fulfillment, economic well-being chasing and life satisfaction. High amounts of economic well-being are progressively valuable for life satisfaction. Salary, a typical indicator of financial status, is all the more positively associated with life satisfaction. Second, sociometric status, i.e., the appreciation and adoration people get in regular day to day existence, is likewise a more grounded indicator of life satisfaction. Financial status was more positively connected with life satisfaction 
(Fors Connolly \& Johansson Sevä, 2018).

Study revealed that there is a connection between the financial status and the self-concept. On the other hand, the findings of this examination fundamentally uncover that there is no measurably significant connection between the perception of self-concept and any of the three parts of the socio-economic factor (Vyas \& Choudhary, 2017).

Whereas, another study was led which demonstrates that fundamental financial components) do influence students' self-esteem (Gasa, Pitsoane, Molepo, \& Lethole, 2018).

\section{METHODS}

\section{1: SETTING}

The study was conducted at Lahore School of Nursing The University of Lahore.

\section{2: RESEARCH DESIGN}

A descriptive correlational study design was used in this study.

\section{3: POPULATION}

Target population of this study was the students of 2 Years Post RN (BSN) and 4 Years Generic BSN.

\section{4: SAMPLING}

Randomized sampling technique was used.

\section{5: RESEARCH INSTRUMENT}

Data was collected from the nursing students by a questionnaire.

\section{6: DATA GATHERING PROCEDURE}

The following research instrument was used to assess the self-esteem and life satisfaction of the students.

(a) Self Esteem Inventory: Self Esteem Inventory was developed by Stanley Cooper smith in 1967.The scale consists of 58 items, these items are marked by two point rating scale "Like Me" and "Unlike me" to score the items.

(b) Satisfaction with Life Scale (SWLS): Satisfaction with Life Scale (SWLS) is a measure of life satisfaction developed by Ed Diener and colleagues (Diner, Emmons, Larsen \& Griffin, 1985). The SWLS consists of 5-items that are completed by the individual whose life satisfaction is being measured. It is a fiveitem scale assessing the cognitive-judgmental component of subjective well-being. Items were rated on a 7-point scale from strongly disagree (1) to strongly agree (7), with higher scores indicating higher life satisfaction

\section{7: ANALYZE DATA}

Data was analyzed on (Statistical Package for Social Sciences) SPSS version 25. Pearson "r" was used for data analysis. Reliability of the data was checked by Chronbach alpha.

\section{8: STUDY TIMELINE}

Study was conducted from 3-02.2019 to 20.04.2019.

\section{9: ETHICAL CONSIDERATION}

The rules and regulations set by the ethical committee of the university of Lahore were followed while conducting the research and the rights of the research participants were respected.

- Written informed consent attached was taken from all the participants.

- $\quad$ All information and data collection was kept confidential.

- $\quad$ Participants were remain anonymous throughout the study.

- $\quad$ The subjects were informed that there were no disadvantages or risk on the procedure of the study.

- They were also informed that they will be free to withdraw at any time during the process of the study.

- Data was kept under key and lock while keeping keys in hand. In laptop it was kept under password.

\section{RESULTS}

This chapter indicates the results of the study which are shown in the form of tables and their description. Table one shows the information about demographic data, Table two provides 
Table: 1

\begin{tabular}{|c|c|c|}
\hline & Characteristics & $\mathbf{N}(\%)$ \\
\hline Gender & $\begin{array}{l}\text { Male } \\
\text { Female }\end{array}$ & $\begin{array}{c}9(7.7 \%) \\
108(92.3 \%)\end{array}$ \\
\hline Age & $\begin{array}{l}20-22 \\
23-25 \\
26-28\end{array}$ & $\begin{array}{l}12(10.3 \%) \\
63(53.8 \%) \\
42(35.9 \%)\end{array}$ \\
\hline Academic programmes of students & $\begin{array}{l}\text { BSN Generic } \\
\text { Post RN }\end{array}$ & $\begin{array}{l}60(51.3 \%) \\
57(48.8 \%)\end{array}$ \\
\hline $\begin{array}{l}\text { Monthly family income of } \\
\text { participants family }\end{array}$ & $\begin{array}{l}>41430 \\
20715-41429 \\
15336-20714 \\
10357-15335 \\
6214-10356 \\
2092-6213 \\
<2091 \\
\end{array}$ & $\begin{array}{c}90(76.9 \%) \\
15(12.8 \%) \\
9(7.7 \%) \\
2(1.7 \%) \\
1(.9 \%)\end{array}$ \\
\hline Education of participants father & $\begin{array}{l}\text { Profession or Honor's } \\
\text { Graduate or Postgraduate } \\
\text { Intermediate or Post High school } \\
\text { Diploma } \\
\text { High school certificate } \\
\text { Middle school certificate } \\
\text { Primary school certificate } \\
\text { Illiterate }\end{array}$ & $\begin{array}{l}93(33.3 \%) \\
18(15.4 \%) \\
20(17.1 \%) \\
9(7.70 \%) \\
16(13.7 \%) \\
3(2.6 \%) \\
12(10.3 \%)\end{array}$ \\
\hline Occupation of participants father & $\begin{array}{l}\text { Profession } \\
\text { Semi profession } \\
\text { Clerical /Shop owner } \\
\text { Skilled worker } \\
\text { Semi-skilled worker } \\
\text { Unskilled worker } \\
\text { Unemployed } \\
\end{array}$ & $\begin{array}{l}43(36.8 \%) \\
16(13.7 \%) \\
13(11.1 \%) \\
22(18.8 \%) \\
7(6.0 \%) \\
7(6.0 \%) \\
9(7.7 \%) \\
\end{array}$ \\
\hline Education of participants mother & $\begin{array}{l}\text { Profession or Honor's } \\
\text { Graduate or Postgraduate } \\
\text { Intermediate or Post High school } \\
\text { Diploma } \\
\text { High school certificate } \\
\text { Middle school certificate } \\
\text { Primary school certificate } \\
\text { Illiterate }\end{array}$ & $\begin{array}{c}33(28.2 \%) \\
11(9.4 \%) \\
16(13.7 \%) \\
18(15.4 \%) \\
13(11.1 \%) \\
11(9.4 \%) \\
15(12.8 \%)\end{array}$ \\
\hline Occupation of participants mother & $\begin{array}{l}\text { Profession } \\
\text { Semi profession } \\
\text { Clerical /Shop owner } \\
\text { Skilled worker } \\
\text { Semi-skilled worker } \\
\text { Unskilled worker } \\
\text { Unemployed }\end{array}$ & $\begin{array}{l}37(31.6 \%) \\
11(9.4 \%) \\
9(7.7 \%) \\
6(5.1 \%) \\
4(3.4 \%) \\
6(5.1 \%) \\
44(37.6 \%)\end{array}$ \\
\hline
\end{tabular}

Table 1: shows the frequency and percentage of demographic data

Table 1 shows the demographic characteristics of the participants. One hundred and seventeen nursing students participate in this study in which 60(51.3\%) BSN and 57(48.8\%) Post RN students in which $9(7.7 \%)$ students were male and $108(92.3 \%)$ were female. 12(10.3\%) were between the age of 20-22. 63(53.8\%) were between the age of $23-25$ and $42(35.9 \%)$ students were between the age of 26-28. 90(76.9\%) students monthly family income was $>41430$ which shows high level of socio-economic status. Monthly family income of $15(12.8 \%)$ students was 20715-41429 which falls in moderate level of socio-economic status and monthly family income of $2(1.7 \%)$ students was 10357-15335 which shows low level of socio-economic status $93(33.3 \%)$ fathers of participants were educated at honors level and 20(17.1\%) were studied at intermediate level. 43(36.8\%) fathers were related to profession and $22(18.8 \%)$ were skilled worker. $33(28.2 \%)$ mothers of the participants were educated at honors level and $15(12.8 \%)$ had only primary certificate. $37(31.6 \%)$ mothers of the participants 
belongs to good profession and 44(37.6\%) were unemployed.

Table: 2

\begin{tabular}{|c|c|c|c|}
\hline \multicolumn{4}{|c|}{ Correlation between life satisfaction and self-esteem } \\
\hline & & \begin{tabular}{|c|} 
Life \\
satisfaction \\
\end{tabular} & Self-esteem \\
\hline \multirow{3}{*}{$\begin{array}{l}\text { Life } \\
\text { satisfactio } \\
n\end{array}$} & Pearson Correlation & 1 & $1.000^{* *}$ \\
\hline & Sig. (2-tailed) & & .000 \\
\hline & $\mathrm{N}$ & 117 & 117 \\
\hline \multirow{3}{*}{$\begin{array}{l}\text { Self- } \\
\text { esteem }\end{array}$} & Pearson Correlation & $1.000^{* *}$ & 1 \\
\hline & Sig. (2-tailed) & .000 & \\
\hline & $\mathrm{N}$ & 117 & 117 \\
\hline
\end{tabular}

Table shows a positive correlation between self-esteem and life satisfaction. Pearson correlation level was 1.000 and $\mathrm{p}$ value was .000 on 0.05 confidence level of interval which shows negative correlation.

Table: 3

\begin{tabular}{|c|c|c|c|c|c|}
\hline \multicolumn{6}{|c|}{ Correlation between independent and dependent variables } \\
\hline & & Gender & Age & SES & Life satisfaction \\
\hline \multirow[t]{3}{*}{ Gender } & $\begin{array}{l}\text { Pearson } \\
\text { Correlation }\end{array}$ & 1 & -.086 & .127 & .008 \\
\hline & Sig. (2-tailed) & & .355 & .173 & .936 \\
\hline & $\mathrm{N}$ & 117 & 117 & 117 & 117 \\
\hline \multirow[t]{3}{*}{ Age } & \begin{tabular}{|l} 
Pearson \\
Correlation
\end{tabular} & -.086 & 1 & .033 & $.350^{* *}$ \\
\hline & Sig. (2-tailed) & .355 & & .723 & .000 \\
\hline & $\mathrm{N}$ & 117 & 117 & 117 & 117 \\
\hline \multirow[t]{3}{*}{ SES } & \begin{tabular}{|l} 
Pearson \\
Correlation
\end{tabular} & .127 & .033 & 1 & -.032 \\
\hline & Sig. (2-tailed) & .173 & .723 & & .733 \\
\hline & $\mathrm{N}$ & 117 & 117 & 117 & 117 \\
\hline
\end{tabular}

Table shows correlation between demographic variables and life satisfaction in which age was seen positively correlated with life satisfaction with $r=.350$ and $p=.000$ at 0.01 (2-tailed) confidence interval.

Table: 4

\begin{tabular}{|c|c|c|c|c|c|}
\hline \multicolumn{6}{|c|}{ Correlation between independent and dependent variables } \\
\hline & & Gender & Age & SES & Self-esteem \\
\hline \multirow[t]{3}{*}{ Gender } & \begin{tabular}{|l} 
Pearson \\
Correlation \\
\end{tabular} & 1 & -.086 & .127 & -.105 \\
\hline & Sig. (2-tailed) & & .355 & .173 & .259 \\
\hline & $\mathrm{N}$ & 117 & 117 & 117 & 117 \\
\hline \multirow[t]{3}{*}{ Age } & \begin{tabular}{|l} 
Pearson \\
Correlation
\end{tabular} & -.086 & 1 & .033 & .034 \\
\hline & Sig. (2-tailed) & .355 & & .723 & .716 \\
\hline & $\mathrm{N}$ & 117 & 117 & 117 & 117 \\
\hline \multirow[t]{3}{*}{ SES } & \begin{tabular}{|l} 
Pearson \\
Correlation \\
\end{tabular} & .127 & .033 & 1 & $.222^{*}$ \\
\hline & Sig. (2-tailed) & .173 & .723 & & .016 \\
\hline & $\mathrm{N}$ & 117 & 117 & 117 & 117 \\
\hline
\end{tabular}

Table shows correlation of demographic variables with self-esteem which was significant at 0.05 (2-tailed). Table: 5

\section{Correlation between demographic variables and sub scales of self-esteem}




\begin{tabular}{|c|c|c|c|c|c|c|c|c|c|}
\hline & & Gen & Age & $\begin{array}{c}\text { Socio- } \\
\text { economic }\end{array}$ & General & Social & Parent & $\begin{array}{c}\text { Academi } \\
\text { c }\end{array}$ & Lie \\
\hline \multirow[t]{3}{*}{ GEN } & $\begin{array}{l}\text { Pearson } \\
\text { Correlatio } \\
n\end{array}$ & 1 & -.086 & .127 & -.051 & -.055 & -.116 & -.043 & -.064 \\
\hline & \begin{tabular}{|l|}
$\begin{array}{l}\text { Sig. } \\
\text { tailed) }\end{array}$ \\
\end{tabular} & & .355 & .173 & .586 & .557 & .216 & .644 & .491 \\
\hline & $\mathrm{N}$ & 117 & 117 & 117 & 117 & 117 & 116 & 117 & 117 \\
\hline \multirow[t]{3}{*}{ AGE } & $\begin{array}{l}\text { Pearson } \\
\text { Correlatio } \\
\text { n }\end{array}$ & -.086 & 1 & .033 & -.013 & .000 & 130 & .056 & .105 \\
\hline & $\begin{array}{ll}\text { Sig. } \\
\text { tailed) }\end{array}$ & .355 & & .723 & .892 & 1.000 & .165 & .552 & .260 \\
\hline & $\mathrm{N}$ & 117 & 117 & 117 & 117 & 117 & 116 & 117 & 117 \\
\hline $\begin{array}{l}\text { SOCIO } \\
- \\
\text { ECON }\end{array}$ & \begin{tabular}{|l|}
$\begin{array}{l}\text { Pearson } \\
\text { Correlatio } \\
\mathrm{n}\end{array}$ \\
\end{tabular} & .127 & .033 & 1 & .159 & .077 & $.247^{* * *}$ & $.307^{* *}$ & .166 \\
\hline \multirow[t]{2}{*}{ OMIC } & \begin{tabular}{|l|}
$\begin{array}{l}\text { Sig. } \\
\text { tailed) }\end{array}$ \\
\end{tabular} & . 173 & .723 & & .086 & .408 & .007 & .001 & .074 \\
\hline & $\mathrm{N}$ & 117 & 117 & 117 & 117 & 117 & 116 & 117 & 117 \\
\hline
\end{tabular}

Table shows correlation between demographic variables and five domains of self-esteem in which socioeconomic status was positively correlated with parent and academic domain of self-esteem

Table: 6

\begin{tabular}{|c|c|c|c|c|}
\hline \multicolumn{5}{|c|}{ Correlation between Socio-economic status, life satisfaction and self-esteem } \\
\hline & & SES Mean & \begin{tabular}{|c} 
LIFE \\
SATISFACTIO \\
$\mathrm{N}$
\end{tabular} & SELF ESTEEM \\
\hline \multirow[t]{3}{*}{ SES Mean } & Pearson Correlation & 1 & $.196^{*}$ & .187 \\
\hline & Sig. (2-tailed) & & .035 & .044 \\
\hline & $\mathrm{N}$ & 117 & 117 & 117 \\
\hline \multirow{3}{*}{$\begin{array}{l}\text { LIFE } \\
\text { SATISFACTION }\end{array}$} & Pearson Correlation & $.196^{*}$ & 1 & $.999^{* *}$ \\
\hline & Sig. (2-tailed) & .035 & & .000 \\
\hline & $\mathrm{N}$ & 117 & 117 & 117 \\
\hline \multirow[t]{3}{*}{ SELF ESTEEM } & Pearson Correlation & $.187^{*}$ & $.999^{* *}$ & 1 \\
\hline & Sig. (2-tailed) & .044 & .000 & \\
\hline & $\mathrm{N}$ & 117 & 117 & 117 \\
\hline \multicolumn{5}{|c|}{ *. Correlation is significant at the 0.05 level (2-tailed). } \\
\hline *. Correlation is & ficant at the 0.01 leve & -tailed). & & \\
\hline
\end{tabular}

Table shows a positive correlation of socio-economic status with self-esteem and life satisfaction

Present study supported alternative hypothesis that there is an association between self-esteem and life satisfaction. So, the null hypothesis is rejected and the alternative hypothesis is accepted. The other null hypothesis that age, gender and socio-economic status have no impact on self-esteem and life satisfaction is rejected and the alternative hypothesis is accepted because there is a positive relation between age and life satisfaction and socio-economic status has an impact on self-esteem.

\section{DISCUSSION}

The main purpose of the study was "to find out the relationship between self-esteem and life satisfaction among nursing students" and "to assess the influence of socio-economic status on self-esteem and life satisfaction nursing students" of University of Lahore. For this purpose Self-esteem Inventory and Satisfaction with life scale were used on nursing students of University aged between 20-28. The results of the study showed positive correlation between self-esteem and life satisfaction. A study supported the results of the present study that there is a positive correlation between self-esteem and life satisfaction and also shows that self-esteem is important factor for satisfaction of life (Hill, 2015). Self-esteem is the perception of a person about oneself. Another study 
showed that self-esteem and life satisfaction has positive relation (Tiwari et al., 2018). A person whose needs are fulfilled is called satisfied. As results of the study showed that most of the students were female So, these findings recommend admission of male nursing student for better services (HANAFI, EL-BILSHA, \& KHATER, 2016). In another study it was suggested to boost up the confidence of male nurses by giving them opportunities to eradicate the lack of community. Self-esteem has different levels and all the students have different range of self-esteem. Studies show that nursing students had average self-esteem. In results the present study no significant relation showed between gender and self-esteem. Previous study supported that there is no significant association between gender and self-esteem (HANAFI et al., 2016). As present study showed that most of the students belong to high socio-economic family. Present study showed that socio-economic status is correlated with self-esteem of the students. Students from high socio-economic status had access to all the physical and other needs. They can manage all matters but the students from low socio-economic status had inadequate resources. So, they cannot meet their basic needs. Students from high socio-economic status showed high level of self-esteem (Mahanty, Sushma, \& Mishra, 2014). Similarly a study supported that income increases the self-esteem and life satisfaction as income decreases it effects on the self-esteem and life satisfaction of the students (Bannink, Pearce, \& Hope, 2016). The results of the study showed a positive correlation between self-esteem and life satisfaction. The main thing which impact on life satisfaction of the students is self-esteem . Rosenberg defined self-esteem as an individual's set of thoughts and feelings about his or her own worth and importance. This definition reflects the notion of "global" or "general" self-esteem or self-worth (Moksnes \& Espnes, 2013).

\section{CONCLUSION}

The present study supported the theoretical framework that socio-economic status had an impact on self-esteem and life satisfaction. Although longitudinal studies are needed to explain causal relations between the variables in the present study, the gender differences on life satisfaction and self-esteem may require gender specific strategies to support the development. It would also be logical to assume that intervention efforts facilitating self-esteem, as one target area among an array of forces, may be central for promoting life satisfaction and positive functioning in the adolescent group. Longitudinal research investigating the reciprocal and dynamic relations between self-esteem and life satisfaction is needed to investigate causality and the generalizability of the results.

\section{LIMITATIONS}

The study was conducted only in nursing students of the university other university students were not included in the study. So, the results were not more generalizable.

\section{ACKNOWLEDGEMENT}

I would like to acknowledge the people who guide me for this study. Firstly, I would like to show greatness $\mathbf{M r}$. Muhammad Afzal (The Principal of Lahore School of Nursing) who permitted me to done this study. I am extremely thankful to Sir Muhammad Hussain for being my preceptor to guide me in research work. I am thankful to all my participants their participation made my research meaningful. Their contribution made this study possible. It is a great preference to have all of these bright people in my life. I thank the administration of the University of Lahore.

\section{REFERENCES}

Agwu, E. M., Draper, S., \& Croix, M. D. S. (2017). Depressive Symptoms Life Satisfaction and Cognitive Health Status Among University Students in Nigeria by Gender and Ethnicity. American Journal of Health Research, 5(2), 2537.

Ahmed, M. (2017). Estimating the Impact of Need Fulfillment on Human Motivation According to Maslow's Hierarchy of Needs. University of Akron.

Al-Attiyah, A., \& Nasser, R. (2016). Gender and age differences in life satisfaction within a sex-segregated society: sampling youth in Qatar. International Journal of Adolescence and Youth, 21(1), 84-95.

Arani, Z. A. A., Hoseini, M. H. M., \& Hamzeei, F. (2018). The Correlation between Spiritual Health and Pleasure in Students of Qom University of Medical Sciences.

Bannink, R., Pearce, A., \& Hope, S. (2016). Family income and young adolescents' perceived social position: associations with self-esteem and life satisfaction in the UK Millennium Cohort Study. Archives of disease in childhood, 101(10), 917-921.

Bieda, A., Hirschfeld, G., Schönfeld, P., Brailovskaia, J., Lin, M., \& Margraf, J. (2019). Happiness, life satisfaction and positive mental health: Investigating reciprocal effects over four years in a Chinese student sample. Journal of Research in Personality, 78, 198-209.

Boyd, K., Lawrence, K., Brooks, J., Perkins, P., \& Clark, V. R. (2018). Relationship Contingent Self-Worth: The Role of Happiness, Well-Being, Self-Esteem, and Depression. Journal of Black Sexuality and Relationships, 4(4), 17-31. 
Burleson, S. E., \& Thoron, A. C. (2014). Maslow's hierarchy of needs and its relation to learning and achievement. Gainesville: Department of Agricultural Education and Communication.

Chen, W., Niu, G.-F., Zhang, D.-J., Fan, C.-Y., Tian, Y., \& Zhou, Z.-K. (2016). Socioeconomic status and life satisfaction in Chinese adolescents: Analysis of self-esteem as a mediator and optimism as a moderator. Personality and Individual Differences, 95, 105-109.

Fors Connolly, F., \& Johansson Sevä, I. (2018). Social status and life satisfaction in context: A comparison between Sweden and the USA. International Journal of Wellbeing, 8(2), 110-134.

Gasa, V., Pitsoane, E., Molepo, L., \& Lethole, P. (2018). The effect of families' socioeconomic status on the self-concept development of learners. Early Child Development and Care, 1-13.

HANAFI, S. K., EL-BILSHA, M. A., \& KHATER, M. E. (2016). A Program to Enhance Self-Esteem among Nursing Students in the Faculty of Nursing at Mansoura University.

HANAFI, S. K., EL-BILSHA, M. A., \& KHATER, M. E. (2016 ). A Program to Enhance Self-Esteem among Nursing Students in the Faculty of Nursing at Mansoura University. Med. J. Cairo Univ.,, 84(1), 5 7-66.

Hill, E. (2015). The Relationship between Self-Esteem, Subjective Happiness and Overall Life Satisfaction. Dublin, National College of Ireland.

Islam, M. R., \& Khan, Z. N. (2017). Impact of socio-economic status on academic achievement among the senior secondary school students. Educational Quest: An International Journal of Education and Applied Social Sciences, 8(2), 665.

Kazemi, Y., Nikmanesh, Z., \& Khosravi, M. (2017). The Relationship Between Quality of Life and Self-esteem and Attribution Styles in Primary School Students. Iranian Journal of Psychiatry and Behavioral Sciences, 11(4).

Khalil, A., Majeed, M. A. I., Bio, A. W., \& Gilani, S. A. (2017). ASSESSMENT OF NURSING STUDENT PERCEPTION TOWARDS, NURSING PROFESSION IN SIR GANGA RAM HOSPITAL AND ITTEFAQ HOSPITAL TRUST LAHORE, PAKISTAN. 29(4).

Körük, S. (2017). The Effect of Self-Esteem on Student Achievement The Factors Effecting Student Achievement (pp. 247257): Springer.

Li, J., Fang, M., Wang, W., Sun, G., \& Cheng, Z. (2018). The Influence of Grit on Life Satisfaction: Self-Esteem as a Mediator. Psychologica Belgica, 58(1), 51.

Mafini, C. (2017). Economic Factors and Life Satisfaction: Trends from South African Communities. Acta Universitatis Danubius. Economica, 13(3).

Mahanty, S., Sushma, B., \& Mishra, M. (2014). SELF ESTEEM AND LIFE SATISFACTION AMONG UNIVERSITY STUDENTS: THE ROLE OF GENDER AND SOCIO-ECONOMIC STATUS.

McGrath, P. J., \& Elgar, F. J. (2015). Behavioral Problems, Effects of Socio-Economic Status on.

Moksnes, U. K., \& Espnes, G. A. (2013). Self-esteem and life satisfaction in adolescents-gender and age as potential moderators. Quality of Life Research, 22(10), 2921-2928.

Norman, P. C. (2016). Teacher attitudes and perceptions of low and high socioeconomic status students.

Okwaraji, E., Godwin, C., Callista, U., \& Emeka, N. (2017). Life Statisfaction, Self Esteem, and Mental Health in a sample of Diabetic Out-Patients Attending a Nigerian Tertiary Health Institution. The Journal of Medical Research, 3(2), 60-65.

Orth, U., Erol, R. Y., \& Luciano, E. C. (2018). Development of self-esteem from age 4 to 94 years: A meta-analysis of longitudinal studies. Psychological bulletin.

Rarau, P., Pulford, J., Gouda, H., Phuanukoonon, S., Bullen, C., Scragg, R., . . Oldenburg, B. (2019). Socio-economic status and behavioural and cardiovascular risk factors in Papua New Guinea: A cross-sectional survey. PloS one, 14(1), e0211068.

Robustelli, B. L., \& Whisman, M. A. (2018). Gratitude and life satisfaction in the United States and Japan. Journal of Happiness Studies, 19(1), 41-55.

Singh, T., Sharma, S., \& Nagesh, S. (2017). Socio-economic status scales updated for 2017. Int J Res Med Sci, 5(7), 32643267.

Tiwari, S. K., Singh, S., Lindinger-Sternart, S., \& Patel, A. K. (2018). Self-esteem and life satisfaction among university students of Eastern Uttar Pradesh of India: A demographical perspective. Indian Journal of Positive Psychology, $9(3)$.

Vyas, S., \& Choudhary, G. (2017). Relationship of socio economic status with frustration, self-concept, study habits and academic achievement of adolescents. International Journal of Advanced Research and Development, 2(3), 46-51. 